\title{
Free Writing Technique in Teaching Writing Skill in EFL Classroom
}

\author{
Paizatul Isni
}

SMA NW Wanasaba, Indonesia

Correspondence: Paizatul Isni, SMA NW Wanasaba, Indonesia. E-mail: isnieversiy@gmail.com

Received: Februari 20, 2018

Accepted: Maret 21, $2018 \quad$ Online Published: April 1, 2018

doi: 10.29408/veles.v2i1.608.g434 URL: http://dx.doi.org/10.29408/veles.v2i1.608.g434

\begin{abstract}
The purpose of this research was to find out the effectiveness of free writing technique in teaching writing for the tenth graders of SMA NW Wanasaba in the school year 2016-2017. Designed as pre-experimental research by using one group pre-test and post-test, it examined a sample of the tenth grade which consisted of 20 students. Writing test was the instrument used to collect the data. In collecting the data, pre-test and pos-test were given to the sample. The data were analyzed through parametric statistic by using SPSS 17.0 for windows. Since the mean score of the pre-test was lower than the mean score of the post-test; it meant that this technique was effective. After submitting the data to a paired samples t-test, it was found that there was a significant difference in the mean scores between the pre-test and the post-test, $\mathrm{t}_{(\mathrm{df}=19)}=-28.803$ at $p=0.000$; it meant that the null hypothesis was rejected and alternative hypothesis was accepted. Thus, this technique was significantly effective in teaching writing for the tenth graders of SMA $N W$ Wanasaba in the school year 2016-2017. Considering the process and the results of this research, the present researcher suggested that the English teacher use free writing technique in teaching writing.

Keywords: free writing technique, writing skill
\end{abstract}

\section{Introduction}

English is an international language that it used almost by all of people in the world. People use it to communicate each other with the other countries. It is used to communicate both in written and spoken languages. In this era, it is very necessary to understand, because it can connect all of people which have different languages, so that's, English is very important to be learned. English is taught in elementary school, secondary school, senior high school, and university level. English teaching aims at mastering four basic skills of language, which include 
listening, speaking, reading, and writing skills. All of the basic skills are able to use English communicatively even written or spoken. One of all of the basic skills that are needed to be mastered is writing.

According to Hadfield (1990), writing is different from speaking. Speaking can acquire it naturally as she/he grows up, but writing needs to be learned first since it could not be acquired naturally. In addition, Harmer (1998, p.79), argues that "writing essentially needs to be learned because it was as a language skill. Writing is also used as reinforcement, language development and learning style". Writing need to be learned about the aspects or master first the aspects are like the grammar, vocabulary, organization, content, and mechanic. All of the aspects must be master by the students. If the students are less in grammar, the students will feel difficult to arrange the vocabulary becomes sentence. By mastering the aspects first to make a good written for the students.

Based on the pre-observation conducted in Class X students of SMA NW Wanasaba, the problems were the students did not know about the aspects of writing skill like grammar, organization, less vocabulary, and contents. Most of the students were low in grammar. It is so difficult for the students to arrange words become a good sentence. And one of the most difficult for the students are difficult to start.

To solve those problems, the present researcher taught recount text using free writing technique. Free writing is an important technique in helping students to express themselves by writing, and it is expected to give students a great start or an introduction to write. It is always better to write something once or at least twice in a day.

It is supported by Bello (1997), who stated that one-way to improve the writing skill is to practice. In this case, the practice will be conducted in form of free writing activity. Whatever the students write about, it is easy to start although the students write about their experience or short story or telling story. The important one is they can start to write.

Elbow, (1998, p.14), found that this free writing activity can help students learn simply to get on writing and not be held by worries about whether they use good words or right words. Free writing is a writing technique that makes students write whatever comes into their head without stopping, worrying about grammar, spelling, organization or even making basic sense. The main aim of free writing is to get something on the page.

Based on the problems identified, the present researcher was interested to know the effectiveness of free writing technique in teaching writing for the tenth graders of SMA NW Wanasaba in the school year 2016-2017.

\section{Method}

The present researcher investigated the effectiveness of free writing technique in teaching writing for the tenth graders of SMA NW Wanasaba in the school year 2016-2017. And the present researcher used pre-experimental design by using one group pre test and post test design. 


\subsection{Participants}

The population of this study was all the tenth grade of SMA NW Wanasaba in the school year 2016-2017, which consisted of 20 students. The sample of this study was the tenth graders of SMA NW Wanasaba in the school year 2016-2017. In taking the number of sample, the present researcher referred to the theory of sampling proposed by Suharsismi $(2002$, p.63) that "if the number of population is less than a hundred, it is better to take all of population as the sample or subject of research but if the number of population is more than a hundred, it is better to take $10-15 \%$ or $20-25 \%$." The present researcher took all of the population as the sample of the study because the population was less than a hundred.

\subsection{Data Collection}

\subsubsection{Instrument of Collecting Data}

Instrument is a tool which is used for collecting data. The instrument used in this research was test. The present researcher used a written test. The test was given to the sample and the result was collected as the data of this research. The test was English written test; the test was in the form of writing recount paragraph to know the students' ability in writing recount text. The present researcher asked the students to write a recount text. The students paid attention on the aspects of writing; content, organization, vocabulary, grammar, and mechanics. In this research, the present researcher gave the same test for pre-test and post-test. According to Cohen (1994, p.307), "evaluation can be a real challenge in that there are numerous things that could logically be evaluated, such as content-depth and breadth of coverage, rhetorical structure-clarity and unity of the thesis, organization-sense of pattern for the development of ideas, registerappropriateness of level of formality, style-sense of control and grace, economy-efficiency of language use, accuracy of meaning-selection and use vocabulary, appropriateness of language conventions-grammar, spelling, punctuation, reader's understanding-inclusion of sufficient information to allow meaning to be conveyed, reader's acceptance-efforts made in the text to solicit the reader's agreement, if so desired". In assessing writing, Cohen recommends an analytical scoring below in Table 01 .

Table 01. Analytic Scoring

\begin{tabular}{cccl}
\hline No & Aspect & Level & \multicolumn{1}{c}{ Criteria } \\
\hline 1 & Contents & 5 & $\begin{array}{l}\text { Excellent; main ideas state clearly and } \\
\text { accurately, change of opinion very clear. } \\
\text { Good; main ideas state fairly clearly and } \\
\text { accurately, change of opinion relatively } \\
\text { clear. }\end{array}$ \\
& 4 & $\begin{array}{l}\text { Average; main ideas somewhat unclear } \\
\text { or inaccurate, change of opinion } \\
\text { statement somewhat weak. }\end{array}$
\end{tabular}


3 Vocabulary

4 Grammar

5 Mechanics
Poor; main ideas not clear or accurate, change of opinion statement weak. Very poor; main ideas not at all clear or accurate, change of opinion statement very weak.
Excellent; well organized and perfectly coherent.

Good; fairly well organized and generally coherent.

Average; loosely organized but main ideas clear, logical but incomplete sequencing.

Poor; ideas disconnected, lacks logical sequencing.

Very poor; no organization, incoherent.

Excellent; very effective choice of words and use of idioms and word forms.

Good; effective choice of words and use of idioms and word forms. Average; adequate choice of words but some misuse of vocabulary, idioms, and word forms.

Poor; limited range, confused use of words, idioms, and word forms. Very poor; very limited range, very poor knowledge of words, idioms, and word forms.

Excellent; no errors, full control of complex structure.

Good; almost no errors, good control of structure.

Average; some errors, fair control of structure.

Poor; many errors, poor control of structure.

Very poor; dominated by errors, no control of structure.

Excellent; mastery of spelling and punctuation. 
4

3

2

1
Good; few errors in spelling and punctuation.

Average; fair number of spelling and punctuation errors.

Poor; frequent errors in spelling and punctuation.

Very poor; no control over spelling and punctuation.

Cohen (1994, p. 328)

Those are the aspects of assessing writing. In each part has different score. When teaching and learning process, teacher should think about how to assess the students ability.

\subsubsection{Techniques for Collecting Data}

In collecting the data, the researcher used pretes, treatment, and posttest. The Pre-test was applied before the present researcher taught writing by free writing technique to the students. It aimed at knowing the students' writing skill. The treatment was conducted after conducting pretest. The present researcher treated the students by applying free writing technique. The treatment was done in two meetings. The Post-test was given by the present researcher after applying treatments. It aimed at knowing the students' achievement on writing after conducting the treatment.

\subsection{Data Analysis}

In this study, the present researcher used SPSS 17 for windows to calculate the data. The present researcher analyzed the mean score and standard deviation by using descriptive statistics. In addition, the present researcher was used the percentage of Students' Error. And then to find out the data has normal distribution or not, the present researcher used One-Sample Kolmogorov-Smirnov $\mathrm{Z}$ and to find out the homogeneity of variance One -Way Anova was used. To know the effectiveness of free writing technique in teaching writing, the present researcher used paired samples t-test.

Based on the data gained, the highest score on pre-test was 36 and the lowest score was 24 with the mean score was 28.20 and standard deviation was 4.00 . While, on post-test, the highest score was 72 and the lowest score was 52 with the mean score was 60.00 and standard deviation was 6.36. The result of descriptive statistics can be seen in Table 2 as follows:

Table 2. The Result of Descriptive Statistics

\begin{tabular}{lcc}
\hline & Pretest & Posttest \\
\hline Mean & 28.20 & 60.00 \\
Std. Deviation & 4.00 & 6.36 \\
\hline
\end{tabular}


Detailed errors of the samples in each aspect of the pre-test showed that contents $13 \%$, organization $10 \%$, grammar $38 \%$, vocabulary $25 \%$, mechanics $14 \%$ and for the post-test was contents $9 \%$, organization $10 \%$, grammar $33 \%$, vocabulary $33 \%$, and mechanics $15 \%$. It can be seen in Table 3 and Table 4 as follows:

Table 3. The Table Percentage of Students' Error of Pre-test

\begin{tabular}{llll}
\hline No & Type of Error & Total Errors & Percentage (\%) \\
\hline 1 & Contents & 81 & $13 \%$ \\
\hline 2 & Organization & 65 & $10 \%$ \\
\hline 3 & Grammar & 246 & $38 \%$ \\
\hline 4 & Vocabulary & 160 & $25 \%$ \\
\hline 5 & Mechanics & 89 & $14 \%$ \\
\hline Total Errors & 641 & 100 \\
\hline
\end{tabular}

Table 4. The Table Percentage of Students' Error of Post-test

\begin{tabular}{llll}
\hline No & Type of Error & Total Errors & Percentage (\%) \\
\hline 1 & Contents & 28 & $9 \%$ \\
\hline 2 & Organization & 29 & $10 \%$ \\
\hline 3 & Grammar & 100 & $33 \%$ \\
\hline 4 & Vocabulary & 102 & $33 \%$ \\
\hline 5 & Mechanics & 44 & $15 \%$ \\
\hline Total & Errors & 303 & 100 \\
\hline
\end{tabular}

Therefore, it could be seen that there was difference between students' writing after and before treatment was implemented. The mean of the students' score after free writing technique had been implemented was higher than mean of the students' score before treatment was implemented.

The calculation of normality testing was used to check whether the distribution of pre-test and post test was normal or not. Moreover, the data are normal if the values of the significance level of pre-test and post-test were more than the values of the significance $p=0.05$. Based on the result of One-Sample K-S, all of the values of Kolmogorov-Smirnov in pre-test and post-test were too much the values of the significance $p=0.05$. The value of Kolmogorov-Smirnov in the pre-test was .98 while the value of significance in post-test was .83 . It implied that the data were normal.

Homogeneity test was conducted to know that the data were homogenous. Moreover, the data are homogenous if the values of the level significance is greater than $p=0.05$. Based on the calculation of One-Way ANOVA, the significant value in pre test was .07 and in post test was .19 It meant that the data were homogeneous. It can be seen in Table 5 as follows: 
Free Writing Technique in Teaching Writing Skill in EFL Classroom

Table 5. The Result of Homogeneity of Variances

\begin{tabular}{lllll}
\hline & Levene Statistic & df1 & df2 & Sig. \\
\hline Pretest & 3.750 & 1 & 18 & .069 \\
\hline Posttest & 1.835 & 1 & 18 & .192 \\
\hline
\end{tabular}

Hypothesis testing was conducted to know whether the null hypothesis was accepted or rejected. To analyze whether there was significant difference in the mean score between the pretest and the post-test, the present researcher used a paired-samples t-test to get answer of the hypothesis. After performing a paired-samples t-test, the present researcher found that there was a significant difference in the mean scores between the pre-test and the post-test, $\mathrm{t}(\mathrm{df}=19)=$ 28.80 at $\mathrm{p}=0.000$; it meant that the null hypothesis was rejected and alternative hypothesis was accepted. The result of the study discovered that free writing technique was effective in teaching writing for the tenth graders of SMA NW Wanasaba in the school year 2016-2017.

\section{Discussion}

After collecting and calculating the data, the researcher found that free writing technique was effective in teaching writing. It can be seen from the result of descriptive statistics where the mean score and standard deviation of pre-test were lower than post-test.

The result after conducting the treatment was there was an improvement of the students' writing. In giving treatment, the researcher allowed the students to find their problems in English writing. After they knew their problems, the researcher guided the students to solve their problems by using the process of free writing technique. The processes of free writing technique in teaching were for the first thing that the students have to do is the students have to choose one idea that makes the students interested. If the students are interested about travelling, the students may take an idea about travelling. The students then write the idea at the top sheet of paper. Everything comes from the students' mind, it should be written by the students without stopping. The teacher motivates the students about: the students have not to think or worry about their grammar. The students just write and write. It improved the students' writing. That why the mean score and standard deviation of post-test was higher than pre-test.

In addition, the data are called homogenous because the values of the level significant was greater than $\mathrm{p}=0.05$. After submitting the data to a paired samples $\mathrm{t}$-test, it was found that there was a significant difference in the mean scores between the pre-test and the post-test, $t(d f=19)=-$ 28.803 at $\mathrm{p}=0.000$; it meant that the null hypothesis was rejected and alternative hypothesis was accepted. The result of the study discovered that free writing technique significantly was effective in teaching writing for the tenth graders of SMA NW Wanasaba in the school year 2016-2017.

The finding in this research shows that the way to make writing become explore for the students is by using free writing technique. This is in line with Elbow, (as cited in Mutmainnah, F., 2016) who stated that the most effective way to improve writing is to do free writing exercises regularly. At least three times a week. They are sometimes called "automatic writing," 
"babbling," or "jabbering" exercises. It also can be useful technique in order to help students start to write. That was why the use of free writing technique in this study was absolutely correct. Furthermore, teachers should provide activities to build students' ability in learning writing and realize that making mistakes in learning a new language is natural.

Another point that should be concerned is the teacher should provide opportunities for learners to write by using group or pair work. In previous teaching technique, the teacher always asked for the students to write by themselves. As a result, the students were not interested $\mathrm{i} / / \mathrm{n}$ learning. By using free writing in learning, it would be easy for them to generate ideas and start writing.

Thus, free writing technique can be used in teaching and learning English writing. This technique makes something more interesting for the students. The teacher can teach writing about recount text easily through this technique. As has been found by the present researcher that in applying the technique in teaching, the present researcher found that there were some advantages like students were easy to start to write. Additionally, students had a good motivation in generating their ideas into a paper.

In conclusion, free writing technique is significantly effective in teaching writing for the tenth graders of SMA NW Wanasaba in the school year 2016-2017.

\section{Conclusion}

Based on results, the present researcher elaborates briefly some conclusions. Those are free writing technique was significantly effective especially for the tenth graders of SMA NW Wanasaba in the school year 2016-2017. The value of the post-test was higher than the value of the pre-test. It meant that the standard deviation and mean score were significant. It was concluded that result of the students' writing ability after treatment were better than before. And after processing the data, the present researcher concluded that there was an effectiveness of free writing technique in teaching writing for the tenth graders of SMA NW Wanasaba in the school year 2016-2017. It can be seen from the result of Paired-Samples t-test where the sig. 2 tailed was lower than 0.05. And there are some suggestions from the researcher such as: the teachers should have some techniques to enrich their English in teaching. So, the students become more excited in learning English especially in writing skill without having any fear to be corrected by the others because of doing grammatical errors, wrong vocabulary, content, organization and mechanics. And the teachers are suggested to be more creative in teaching writing because by treating those with some good techniques, the students' will be challenged and be more enthused in studying English especially in writing skill. By giving the students practice more every time, the students' can write English well. Meanwhile, the free writing technique can be one of the alternatives to be used in teaching their English writing.

\section{References}


Alsamadani, H.A .2010. The Relationship between Saudi EFL Students' Writing Competence, L1 Writing Proficiency, and Self-regulation. College of Education, Um-Alqura University. European Journal of Social Sciences - Volume 16, Number 1

Butcher, Susan E. (2006) Narrative as a Teaching Strategy. The Journal of Correctional Education 57(3)

Campbell, Terry A (2009) Storytelling and Story Writing "Using a Different Kind of Pencil" Nipissing University and Michelle Hlusek, Nipissing-Parry Sound Catholic District School Board

Cahyono, B.Y. \& Widiati.U.. 2011. The Teaching of English as a Foreign Language in Indonesia. Malang. State University of Malang.

Depdiknas, 2006. Kurrikulum Tingkat Satuan Pendidikan (School Based Curriculum). Jakarta: Depdiknas.

Ghosn, I.K. 2000. Four Good Reasons to Use Literature in Primary School ELT. ELT Journal, 56(2): 172-179

Harmer, J. 1998. How to Teach English: An Introduction to the Practice of English Language Teaching. London: Addison Wesley Longman Limited.

Jalango, M.R. 1992. Early Childhood Language Arts. Massacussets: Allyn and Bacon

Karlisson, Patience A. (2012) Storytelling as a Teaching Strategy in the English Language Classroom in Iceland. M.Ed. thesis in the teaching and learning of foreign languages, Faculty of Teacher Education School of Education, University of Iceland

Miller, Sara and Pennycuff, Lisa. 2008. The Power of Story: Using Storytelling to Improve Literacy Learning. Journal of Cross-Disciplinary Perspectives in Education Vol. 1, No. 1 (May 2008) 36-43

Richard, J. C, and Renandya, W. A.2002. Methodology in Language Teaching: An Anthology of Current Practice. United Kingdom. Cambridge University Press.

Short, D. J.1999. New Ways in Teaching English at the Secondary Level. USA, Bloomington, TESOL.Inc.

Tomlinson, C.M., and Brown, C.L. 2002. Essential of Children's Literature. Boston: Allyn and Bacon

Wright, A. 1995. Storytelling with Children. Oxport: Oxport University Press. 